\title{
RBFOX1 Gene
}

National Cancer Institute

\section{Source}

National Cancer Institute. RBFOX1 Gene. NCI Thesaurus. Code C98194.

This gene plays a role in mRNA processing. 